\title{
Histopathology, bacteriology and experimental transmission of cold-water vibriosis in Atlantic salmon Salmo salar
}

\author{
David W. Bruno, Trevor S. Hastings \& Anthony E. Ellis \\ Department of Agriculture and Fisheries for Scotland, Marine Laboratory, Victoria Road, Aberdeen AB9 8DB, Scotland
}

\begin{abstract}
In Scotland, low level mortalities in farmed Atlantic salmon were associated with a bacterium which had properties generally associated with the genus Vibrio, but which did not resemble any previously described species. In naturally infected fish extensive sloughing and necrosis of the gut mucosa, haemorrhaging, and an increase in peritoneal exudate were recorded. Similar lesions were produced in Atlantic salmon Salmo salar L. experimentally infected with the bacterium. This disease outbreak resembles the condition referred to as 'Hitra disease' in Norway.
\end{abstract}

\section{INTRODUCTION}

In Norway, mortalities associated with a Vibrio-like bacterium have occurred among farmed Atlantic salmon Salmo salar L. since autumn and winter of 1979/ 80. Egidius et al. (1981) referred to this as 'cold-water vibriosis' or 'Hitra disease' after the region where it was first recorded. The condition was induced experimentally in rainbow trout, Salmo gairdneri Richardson, following injection of the isolated bacteria. Poppe et al. (1985) described a similar condition in Atlantic salmon which they referred to as 'haemorrhagic syndrome', and suggested that this represented a 'multifactorial productional disease' influenced by nutritional factors. The isolated bacteria were believed to be ubiquitous in the marine environment and could infect severely weakened and stressed fish. Another Norwegian group (Fjolstad \& Heyeraas 1985) described 'Hitra disease' as a condition involving muscular and myocardial degeneration in farmed salmon but in this case a bacterial infection was not implicated and vitamin E/selenium deficiency was suggested as the cause. Clearly some confusion has arisen with the use of the term 'Hitra disease', and for the purpose of this study the term cold-water vibriosis is used.

During January 1985 a low level mortality was reported from a sea cage unit rearing Atlantic salmon Salmo salar in the Shetland Islands, Scotland. This disease outbreak was found to be associated with a Vibrio species distinct from Vibrio anguillarum and $V$. ordalii. Our preliminary observations on this disease outbreak were reported by Bruno et al. 1985. A culture of the bacterium isolated from moribund fish (MT 171) was deposited with the National Collection of Marine Bacteria Ltd., Aberdeen, as NCMB 2245. The available evidence suggested that this condition was similar to the 'cold-water vibriosis' recorded in Norway by Egidius et al. (1981).

This study describes gross and microscopic lesions associated with cold-water vibriosis, biochemical properties of the isolated bacterium, and studies on experimental transmission.

\section{MATERIALS AND METHODS}

Bacteriology. An inoculum was aseptically taken from kidney, swim bladder, peritoneal fluid and rectum of moribund farmed stock streaked onto tryptic soy agar (TSA) (Difco) containing $2 \% \mathrm{NaCl}_{\text {, }}$ and incubated at $15^{\circ} \mathrm{C}$ for $48 \mathrm{~h}$. Colony morphology of these isolates was recorded after $6 \mathrm{~d}$. To determine biochemical and enzyme profiles of the bacterium, pure cultures were suspended in $2 \%$ marine salts and used to inoculate API 20E, API $50 \mathrm{CH}$, and API ZYM test strips (API Laboratory Products). The $20 \mathrm{E}$ and $50 \mathrm{CH}$ tests were incubated at $15{ }^{\circ} \mathrm{C}$ and the ZYM at $22{ }^{\circ} \mathrm{C}$, both for $48 \mathrm{~h}$. Additional biochemical tests were carried out according to MacFaddin (1980).

Histopathology. Tissues were removed from 
moribund farmed fish and fixed in buffered formal saline, embedded in paraffin wax. Sections were cut and stained with haematoxylin and eosin ( $\mathrm{H} \& \mathrm{E})$, or Giemsa stain.

Experimental transmission. Apparently healthy Atlantic salmon post-smolts (mean weight $244 \mathrm{~g}$; mean length $28 \mathrm{~cm}$ ), reared from eggs at a Marine Laboratory site, were anaesthetized in $25 \mathrm{mg} \mathrm{l}^{-1}$ ethyl-paminobenzoate (benzocaine). Four fish (Group A) were injected intraperitoneally (ip) with $0.2 \mathrm{ml}$ of a suspension $\left(5.2 \times 10^{5} \mathrm{ml}^{-1}\right.$ ) of NCMB 2245 (from a $5 \mathrm{~d}$ agar culture) in phosphate-buffered saline (PBS), pH 7.3. Four fish (Group B) were adipose fin-clipped and injected ip with $0.2 \mathrm{ml}$ of a $1 / 100$ dilution of this bacterial suspension. All the fish were returned to seawater tanks to recover and observed for $10 \mathrm{wk}$. The water temperature remained between 5 and $6{ }^{\circ} \mathrm{C}$. Tissues from moribund fish were sampled for bacteriology and histology.

\section{RESULTS}

\section{Field observations}

Low level mortality was reported during January 1985 following grading of farmed Atlantic salmon Salmo salar that had been in seawater for less than $1 \mathrm{yr}$ and that weighed between 1.0 and $1.5 \mathrm{~kg}$. Water temperature was $7^{\circ} \mathrm{C}$. A $14 \mathrm{~d}$ treatment with oxytetracycline was commenced and mortalities were subsequently controlled. Towards the end of February there was a recurrence of this condition and further mortalities. The antibiotic treatment was repeated in March. The cumulative mortality was held to $3 \%$ of the population.

\section{Properties of bacterial isolate NCMB 2245}

Pure bacterial cultures were obtained on TSA $+2 \%$ $\mathrm{NaCl}$ from kidney, swimbladder and peritoneal fluid of moribund farmed fish sampled in January 1985, and again in February and March when similar disease signs were also observed. After $3 \mathrm{~d}$ growth on $\mathrm{NaCl}$ supplemented TSA at $15^{\circ} \mathrm{C}$, isolates appeared as small $(0.5 \mathrm{~mm})$, circular, smooth, entire, translucent colonies.

Pure cultures were isolated from kidney and rectum of moribund laboratory-infected Atlantic salmon (Group A) at 38 and $44 \mathrm{~d}$ post-injection. All isolates were Gram-negative, motile, pleomorphic curved rods, approximately $0.5 \times 1$ to $4.0 \mu \mathrm{m}$, and were inhibited by the vibriostatic compound 0/129 (2,4-diamino 6,7disopropyl pteridine phosphate, $10 \mu \mathrm{g}$ disc). Optimum growth was obtained in the presence of $1.5 \% \mathrm{NaCl}$. In seawater broth, growth occurred between 5 and $20^{\circ} \mathrm{C}$ but not at $30^{\circ} \mathrm{C}$. Biochemical properties for NCMB 2245 using the API $20 \mathrm{E}$ and API 50CH test systems are given in Table 1 . Other positive biochemical properties were catalase and DNase production and haemolytic action on horse erythrocytes. Negative reactions

Table 1. Vibrio sp. NCMB 2245. Biochemical properties + Reaction; - no reaction; (+) weak reaction

\begin{tabular}{|c|c|c|c|}
\hline Cytochrome oxidase & + & Glycerol & $(+)$ \\
\hline$\beta$-galactosidase production & - & D-mannose & t \\
\hline Arginine dihydrolase & - & L-sorbose & - \\
\hline Lysine decarboxylase & - & Dulritnl & \\
\hline Ornithine decarboxylase & - & Amygdalin & - \\
\hline Tryptophan deaminase & - & Arbutin & - \\
\hline Citrate utilization (Simmons) & + & Aesculin & - \\
\hline Hydrogen sulphide production & - & Salicin & - \\
\hline Urease production & - & Cellobiose & - \\
\hline Gelatin liquefaction & - & Maltose & + \\
\hline Indole production & - & Lactose & - \\
\hline Voges-Proskauer & - & $\begin{array}{l}\text { Trehalose } \\
\text { Inulin }\end{array}$ & $\begin{array}{l}+ \\
-\end{array}$ \\
\hline Acid production from: & & Melezitose & - \\
\hline Erythritol & - & D-raffinose & - \\
\hline D-arabinose & - & Amidon & - \\
\hline L-arabinose & - & Glycogen & - \\
\hline Ribose & + & Xylitol & - \\
\hline D-xylose & - & $\beta$-gentiobiose & - \\
\hline L-xylose & - & D-turanose & - \\
\hline Adonitol & - & D-lyxose & - \\
\hline$\alpha$-methyl-xyloside & - & D-tagatose & - \\
\hline Galactose & + & D-fucose & - \\
\hline D-glucose & + & L-fucose & \\
\hline$D$-fructose & + & D-arabitol & - \\
\hline Mannitol & + & L-arabitol & - \\
\hline Inositol & - & Gluconate & + \\
\hline Sorbitol & $(+)$ & 2 ceto-gluconate & - \\
\hline$\alpha$-methyl-D-mannoside & - & 5 ceto-gluconate & - \\
\hline$\alpha$-methyl-D-glucoside & - & & \\
\hline N-acetyl glucosamine & + & & \\
\hline Rhamnose & - & & \\
\hline Sucrose & - & & \\
\hline Melibiose & - & & \\
\hline
\end{tabular}

were recorded for gelatinase, reduction of nitrates, Tween 80 hydrolysis and starch hydrolysis. Poor growth and a weak fermentative reaction occurred in marine $\mathrm{O}-\mathrm{F}$ glucose medium. All isolates were sensitive to discs containing oxolinic acid $(2 \mu \mathrm{g})$, oxytetracycline $(25 \mu \mathrm{g})$, trimethoprim $(2.5 \mu \mathrm{g})$, furazolidone $(200 \mu \mathrm{g})$ and sulphadiazine $(200 \mu \mathrm{g})$. Positive reactions for NCMB 2245 in the 'API ZYM' tests were alkaline phosphatase, esterase $\mathrm{C} 4$, esterase lipase C8, lipase C14, leucine arylamidase, valine arylamidase, acid phosphatase, phosphoamidase, $\mathrm{N}$-acetyl- $\beta$ glucosaminidase, and mannosidase. 


\section{Lesions in farmed Atlantic salmon}

No external lesions were recorded. Internally the fish appeared well nourished. Petechial haemorrhaging occurred between the caeca, in abdominal fat and the kidney. There was an accumulation of bloody fluid in the peritoneal cavity. The spleen was generally bright red. The gut, particularly the rectal region, was haemorrhagic and the contents watery.

In histological sections stained with $H \& E_{\text {, the }}$ mucosa of the caeca and mid and hind intestine were necrotic and sloughing into the lumen (Fig. 1a). Extensive vasodilation, congestion of blood vessels, and haemorrhaging was present in the lamina propria along with greatly increased numbers of eosinophilic granular cells (EGC), (Fig. 1a, arrowed). In some cases there was necrosis of the entire mucosal epithelium. EGCs were also present in very large numbers in the bulbous arteriosus and atrium. Many of these cells appeared to be degranulating. The heart tissues were otherwise normal.

In the kidney, haemopoietic tissue was sparse with areas of focal necrosis where macrophages with greyish granular cytoplasm predominated. Melanomacrophages in the kidney were sparse. The nuclei of glomerular epithelial cells were frequently swollen and the cells occasionally necrotic. Kidney tubule cells occasionally appeared vacuolated in the basal cytoplasm.

The ellipsoid system within the spleen was greatly enlarged and was comprised of large macrophage-like cells with a granular appearance (Fig. 1b). Focal necrosis of the reticuloendothelial cells was recorded. The splenic pulp contained few leucocytes. Gills showed varying degrees of epithelio-capillary separation, epithelial necrosis and sloughing. There appeared to be increased melanin underlying the epithelium of the primary filaments. Liver and pancreas were normal.

In sections stained with Giemsa, large numbers of bacteria could be seen particularly within enlarged walls of splenic ellipsoids. Bacteria were seen free and within leucocytes, scattered throughout the haemopoietic tissue and glomerulus of the kidney, and within blood vessels and sinuses of the gut, liver, and pancreas. Large colonies of bacteria were seen in the tissues of the bulbous arteriosus and ventricle (Fig. 1c). Few bacteria were present within the gills and none were seen in the kidney tubules or the gut lumen.

Lesions in farmed fish sampled in February were less severe than in those sampled in January. In particular, enteritis was slight, gills and heart were normal, and focal necrosis in the kidney was slight. While many bacteria were present in the ellipsoids of the spleen, hypertrophy of these cells was not as pronounced. In a recurrence of the disease in March, lesions were similar but not as severe. Bacteria were present in high numbers only in the splenic ellipsoids which were enlarged by otherwise normal in appearance. Bacteria were again observed in most other tissues but only in very low numbers

\section{Pathological changes in experimentally infected Atlantic salmon}

Two fish in Group A became moribund at 38 and 44 $\mathrm{d}$ post-injection. No mortalities were recorded from the remaining 2 fish in Group A nor the fish in Group B. Bacteria were not isolated from surviving fish in either group at Day 70.

The first signs in the 2 affected fish were a loss of balance followed by the appearance of a bloody fluid from the vent. Internally the liver was pale, the intestine and swimbladder were haemorrhagic, and there was bloody fluid in the peritoneal cavity. Pure cultures of bacteria were isolated on TSA $+2 \% \mathrm{NaCl}$ from kidney, swimbladder and the peritoneal fluid. Morphological and biochemical properties of these bacteria were indistinguishable from those of NCMB 2245.

Sections were stained with $\mathrm{H} \& \mathrm{E}$ and also with Giemsa to discern bacterial cells. In the intestine, bacteria were present within phagocytic cells. However, the bacteria also occurred free within blood vessels, the lamina propria, and the lumen of the intestine. Many EGCs were present in the lamina propria. Widespread vasodilatation was apparent. The mucosa were generally intact but petechial haemorrhages coincided with underlying high concentrations of bacteria.

The spleen possessed the highest concentrations of bacteria with large colonies scattered throughout the tissue. The ellipsoids had degenerated leaving only a connective tissue framework. Few leucocytes were present and the tissue was engorged with erythrocytes.

The kidney exhibited few lesions. Bacteria occurred within phagocytes or free, within the haemopoietic tissue and glomerular blood vessels, but their numbers were low.

The swimbladder showed vasodilatation, petechial haemorrhaging and focal necrosis in all layers (Fig. $1 d)$. The connective tissue was oedematous. Severe lesions were populated by large numbers of bacteria. In the other tissues examined (heart, ovary, gall bladder, liver, pancreas, gills), bacteria, free and phagocytosed, were present in variable numbers, but there were no striking lesions.

It was concluded there were no differences in the lesions of naturally infected Atlantic salmon and those of fish experimentally infected in the laboratory. 


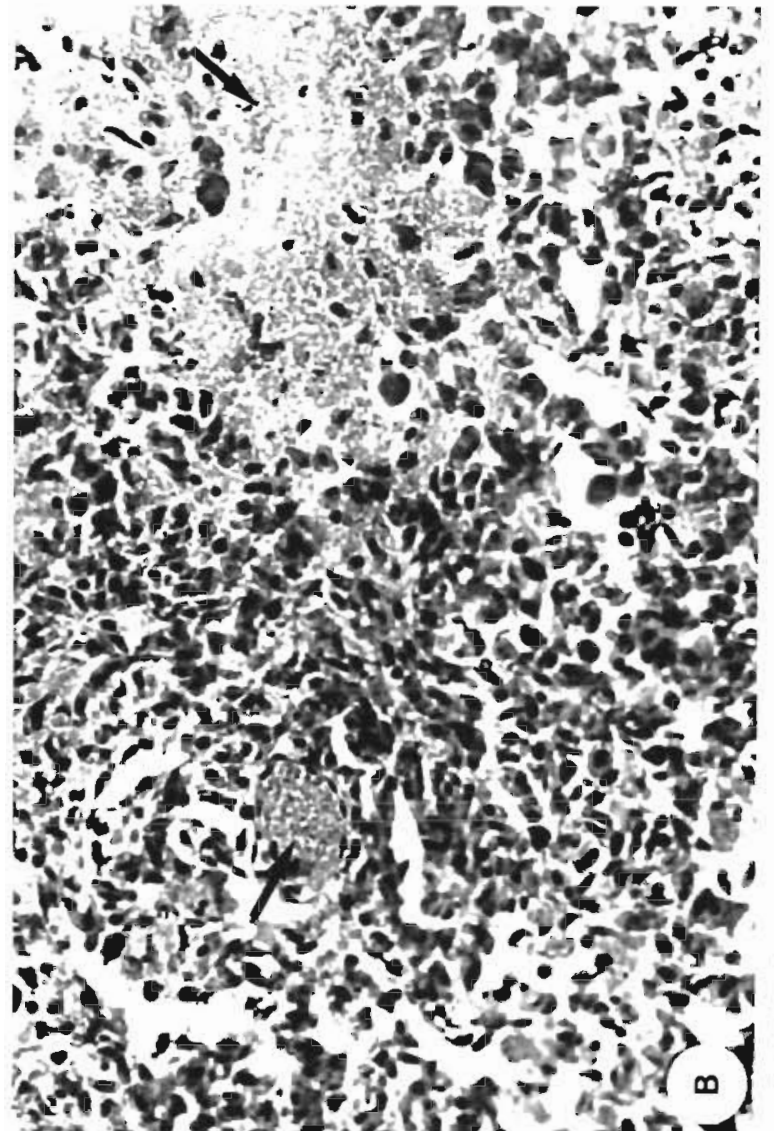

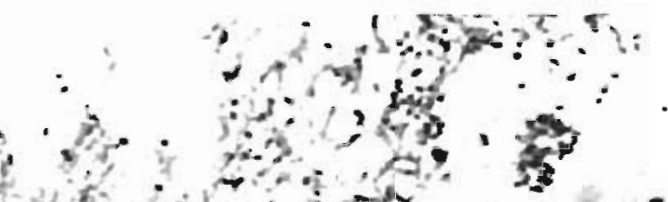

$$
\begin{aligned}
& \text { at }
\end{aligned}
$$

Lit 1 -

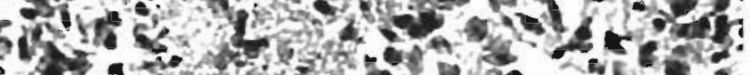
4. Tyo

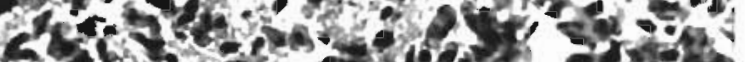

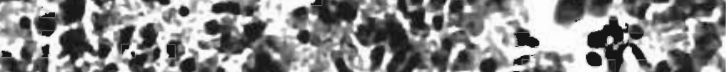

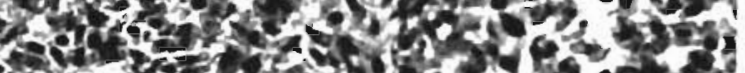

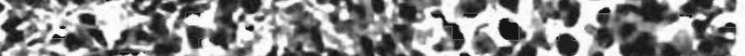

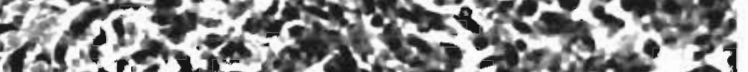

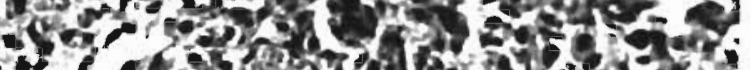

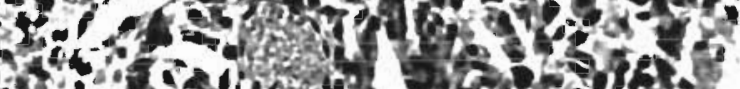

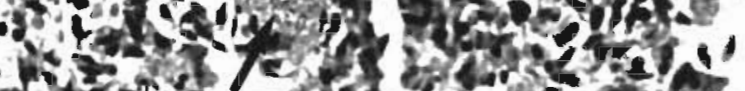

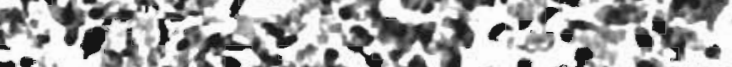

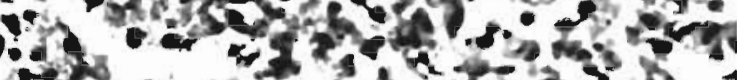

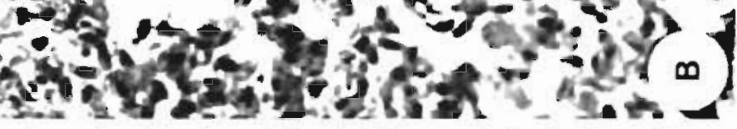

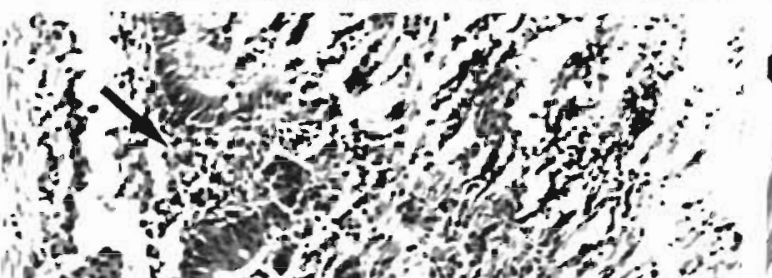
un

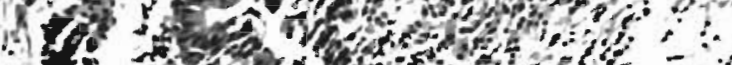

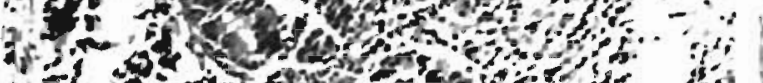
1 -

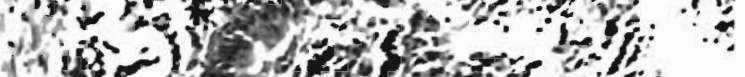
1. n 1.

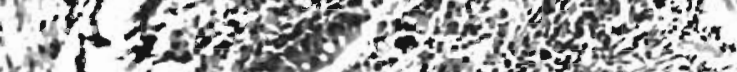
l

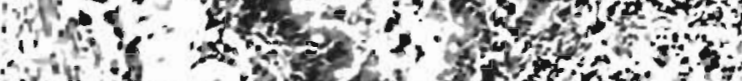

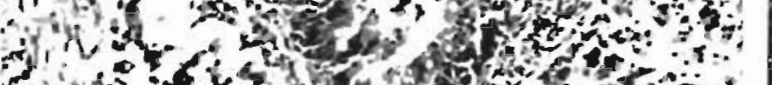

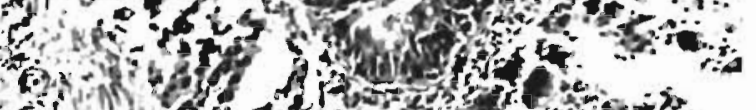
Q

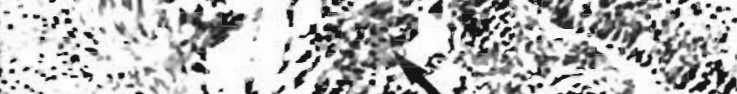
$\therefore$ ot

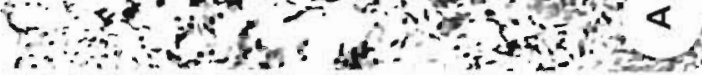
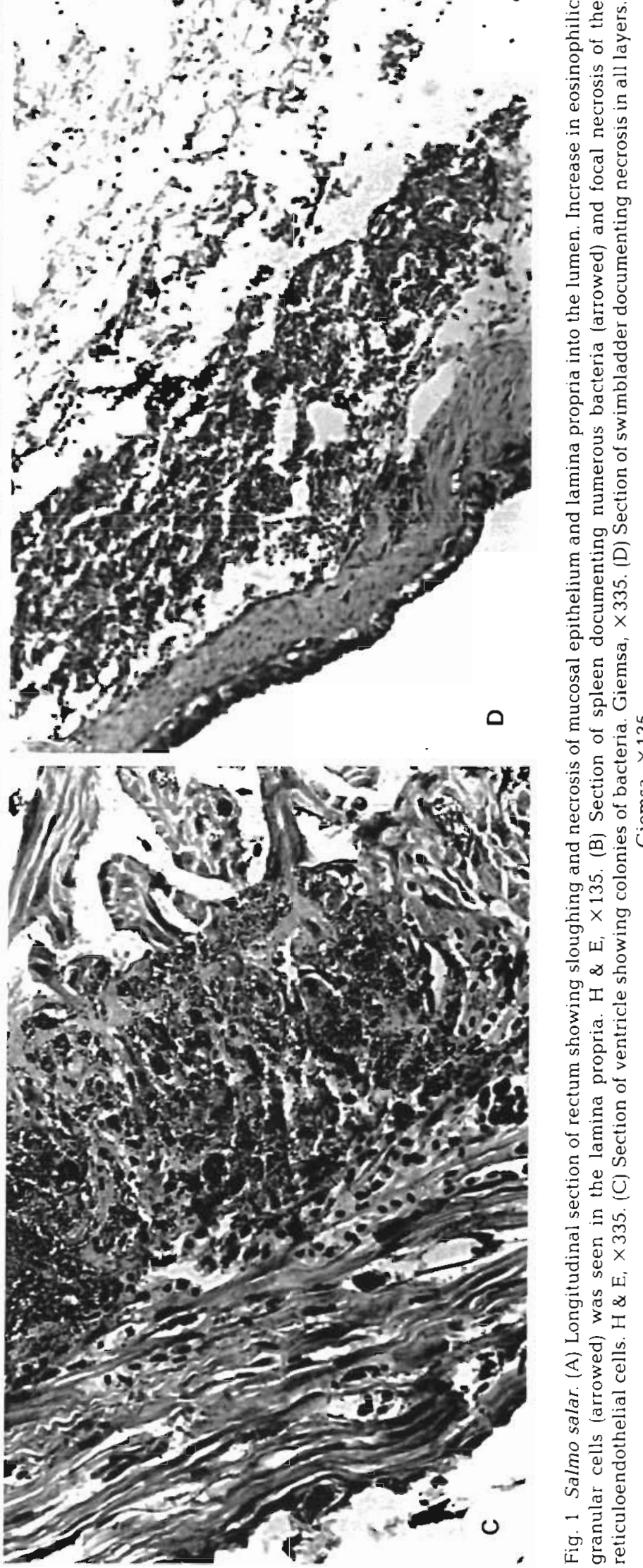


\section{DISCUSSION}

This account reports that mortalities in a sea cage Atlantic salmon farm in Shetland were of bacterial aetiology. The disease we describe here resembles the descriptions given by Egidius et al. (1984) and Soleim (1985) for a disease variously called 'Hitra disease', 'cold-water vibriosis' or 'haemorrhagic syndrome' by various Norwegian workers, the aetiology of which is disputed.

The biochemical properties of the bacterium causing cold-water vibriosis in Shetland indicate it to be a Vibrio sp. that differs from other members of the genus Vibrio (Kent 1982, Baumann et al. 1984, Dawson \& Sneath 1985). The biochemical properties of bacteria isolated from moribund Atlantic salmon by Holm et al (1985) and Poppe et al. (1985) are very similar to those described in this study. The isolates examined differed from $V$. anguillarum and $V$. ordalii because nitrate was not reduced, gelatin was not liquefied and sucrose was not fermented. Holm et al. (1985) and Poppe et al. (1985) found the 'Hitra' isolates did not produce acid from trehalose, and Holm et al. (1985) reported fermentation of maltose, while Poppe et al. (1985) found the latter reaction to be variable. It is concluded that the Norwegian and Shetland bacterial strains have many properties in common and are distinct from $V$. anguillarum and $V$. ordalii.

Successful laboratory infection of rainbow trout was established by Egidius et al. (1981). At $9^{\circ} \mathrm{C}$, disease signs appeared $9 \mathrm{~d}$ after the intraperitoneal injection of the suspect bacterium, with mortalities occurring a few days later. Unfortunately, there was no reference to the number of bacteria injected. In the present study, the

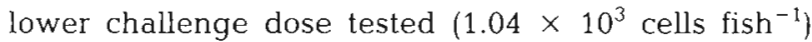
did not establish infections. However, experimental infection was achieved by inoculating $1.04 \times 10^{5}$ bacteria ip into post-smolts. The disease was slow to appear ( 38 to $44 \mathrm{~d}$ ) and the bacterium was recovered in pure culture. These findings support the conclusion that the Shetland outbreak was a disease of bacterial origin.

Laboratory infection results suggest that the bacterium may be best detected in the splenic ellipsoids where it occurs in the highest numbers. It seems likely that during the course of infection bacteria proliferate in many tissues and circulate freely. Circulating bacteria are apparently phagocytosed by the splenic ellipsoid macrophages. One can speculate that the replete ellipsoid macrophages break down and that the released bacteria increase in numbers, producing the severe bacteraemia. Bacterial cells were evidently phagocytosed at an early stage as shown by the very large numbers of bacteria-containing phagocytes in blood vessels but there was no evidence for destruction of bacteria within phagocytes as judged by our histological methods. It is likely, therefore, that this bacterium is able to survive within phagocytes. This may explain why there was a recurrence of this disease after antibiotic therapy since such treatment may not kill all intracellular bacteria.

Pathological changes associated with the disease are consistent with those described by several Norwegian workers. The first disease signs reported by Egidius et al. (1984) and Poppe et al. (1985) were fish swimming on their sides in the upper water alongside the net. These fish also exhibited extensive haemorrhaging around the gill cavity and vent region. Although external signs were not recorded in the affected Scottish farm stock, laboratory infected fish also showed a loss of balance and a bloody fluid from the vent. Internally, extensive haemorrhaging on the swimbladder, caeca and abdominal fat was the most characteristic sign in this study, corresponding with affected Atlantic salmon in Norway (Egidius et al. 1981, 1984, Poppe et al. 1985). The kidney lesions recorded in this study are similar to those described by Soleim (1985). Other lesions described by Fjolstad \& Heyeraas (1985) and Poppe et al. (1985) including myocardial degeneration, zonal necrosis, and fatty degeneration of the liver parenchyma were not recorded in this study. It is interesting to note that Poppe et al. (1985) recovered an isolate (A996/82) from diseased Atlantic salmon with several properties common to those reported in this study. However this isolate was not considered to be the cause of mortalities in Norway, and it was suggested that similar bacteria are ubiquitous in the marine environment and may invade the tissues of weakened and stressed fish. Furthermore, no bacterial growth was obtained from 'Hitra'-diseased fish in the study by Fjolstad \& Heyeraas (1985). On this basis, both groups of workers have suggested the avoidance of this condition might be achieved by modifying current fish cultural practices.

In the Shetland outbreak, fish were fed exclusively on a commercial pelleted feed commonly used throughout Scotland. No comparable disease has been reported on the other farms using this diet, supporting the conclusion that nutritional factors were not the cause of the Shetland outbreak. It should be noted that Norwegian salmon are often fed on raw marine fish of uncertain nutritional status plus vitamin and mineral supplements. It is possible that the discrepancy between the Norwegian workers' findings on the 'Hitra syndrome' may arise from the presence of 2 primary problems, one nutritional and one bacterial, which may or may not occur together.

Acknowledgements. The authors gratefully acknowledge the assistance of Miss A. McKay (Marine Laboratory) and Mrs A. J. Baxter (National Collection of Marine Bacteria Ltd). 


\section{LITERATURE CITED}

Baumann, P., Furniss, A. L., Lee, J. V. (1984). Facultatively anaerobic Gram-negative rods. In: Kreig, N. R., Holt, J. G. (ed.) Bergey's manual of systematic bacteriology, Vol. 1. Williams \& Wilkins, Baltimore/London, p. 518-538

Bruno, D. W., Hastings, T. S., Ellis, A. E., Wootten, R. (1985). Outbreak of a cold water vibriosis in Atlantic salmon in Scotland. Bull. Eur. Assoc. Fish Pathol. 5: 62-63

Dawson, C. A., Sneath, P. H. A. (1985). A probability matrix for the identification of vibrios. J. appl. Bact. 58: 407-423

Egidius, E., Andersen, K., Clausen, E., Raa, J. (1981). Coldwater vibriosis or 'Hitra disease' in Norwegian salmonid farming. J. Fish Dis. 4: 353-354

Egidius, E., Soleim, O., Andersen, K. (1984). Further observations on cold-water vibriosis or Hitra disease. Bull. Eur. Assoc. Fish Pathol. 4: 50-51

Fjolstad, M., Heyeraas, A. L. (1985). Muscular and myocardial degeneration in cultured Atlantic salmon, Salmo salar L., suffering from 'Hitra disease'. J. Fish Dis. 8: 367-372
Holm, K. O., Strom, E., Stensvag, K., Raa, J., Jorgensen, T. (1985). Characteristics of a Vibrio sp associated with the 'Hitra Disease', of Atlantic salmon in Norwegian fish farms. Fish Path. 20: 125-129

Kent, M. L. (1982). Characteristics and identification of Pasteurella and Vibrio species pathogenic to fishes using API-20E (Analytab products) multitube test strips. Can. J. Fish Aquat. Sci. 39: 1725-1729

MacFaddin, J. F. (1980). Biochemical tests for the identification of medical bacteria. Williams and Wilkins, Baltimore 2nd Ed

Poppe, T. T., Hastein, T., Salte, R. (1985). 'Hitra disease (Haemorrhagic syndrome) in Norwegian salmon farming: Present status. In: Ellis, A. E. (ed.) Fish and shellfish pathology. Academic Press, London p. 223-229

Soleim, O. (1985). Kidney histology of Atlantic salmon (Salmo salar) suffering from cold-water vibriosis or Hitra-disease. Bull. Eur. Assoc. Fish Pathol. 5: 88-89

Responsible Subject Editor: Dr. T. Evelyn; accepted for printing on July 28, 1986 